\title{
Thermoregulation of a Semi-aquatic MammaI, the Muskrat, in Air and Water
}

\author{
Jon SHERER \& Bruce A. WUNDER
}

\begin{abstract}
Sherer J. \& Wunder B. A., 1979: Thermoregulation of a semi-aquatic mammal, the muskrat, in air and water. Acta theriol., 24, 19: 249-256 [With 1 Table \& 2 Figs.]

Oxygen consumption and body temperature $\left(T_{B}\right)$ were determined for muskrats Ondatra zibethicus ( $\mathrm{L}$ innae us 1766) following $45 \mathrm{~min}$ of exposure to air and water temperatures ranging from 5 to $30^{\circ} \mathrm{C}$. On two occasions the muskrats were fasted for $48 \mathrm{~h}$ previous to testing in air and water at $5^{\circ} \mathrm{C}$. Muskrats showed a stable $\mathrm{T}_{\mathrm{B}}$ in air, but marked hypothermia upon exposure to cold water. Although all muskrats had lower $\mathrm{T}_{\mathrm{B}}$ in water than air some raised metabolism and sustained only limited hypothermia. Others did not elevate metabolic rate appreciably and become quite hypothermic.

[Dept. Zool.-Entomol., Colorado State Univ., Fort Collins, Colorado 80523, USA]
\end{abstract}

\section{INTRODUCTION}

Given its northern distribution, the muskrat Ondatra zibethicus: ( $\mathrm{L}$ in n a e us, 1766), a non-hibernating, semi-aquatic mammal, is often subjected to rather severe cold stress. Although the muskrat spends most. of the winter beneath snow and ice, and is seldom exposed to air temperatures below freezing ( $\mathrm{J} \circ \mathrm{h}$ a n s e n, 1962), it is regularly submerged in near-freezing water. Because of its high thermal conductivity (relative to air), cold water has been described by Irving \& H a r t (1957) as the environment most conducive to heat loss of all environments encountered by mammals.

Johansen (1962) showed that the muskrat's non-wettable fur retains an insulating layer of air at the body surface when submerged. He suggested that the insulation afforded by this layer allows the muskrat to remain warm when submerged in near freezing water. $\mathrm{H}$ a $\mathrm{rt}$ (1962), however, presented data suggesting that muskrats become hypothermic when exposed to cold water, despite an increased metabolic heat production.

Thus, we undertook this study to examine the muskrat's thermoregulatory ability both in air and water and to determine the energetic cost. 
of maintaining homeothermy in the two environments. We also investigated effects of food deprivation on thermoregulatory ability since there may be times in the winter when food is difficult for muskrats to obtain. Previous studies have investigated seasonal changes in metabolism of muskrats (A leksiuk \& Frohlinger, 1971) and postdiving oxygen consumption ( $\mathrm{Fa}$ ir banks \& $\mathrm{Kilg}$ ore, 1978), but none has looked at effects of submersion in water.

\section{MATERIALS AND METHODS}

Ten muskrats ( 4 male, 6 female) were trapped in the vicinity of Fort Collins, Larimer County, Colorado between October, 1974 and June, 1975. The animals were housed individually in the laboratory in wire cages measuring $90 \times 90 \times 90 \mathrm{~cm}$. They were provided with wooden nest boxes and a pan of water large enough to bathe in. The water was changed and the animals were fed fresh lettuce and commercial rabbit pellets daily. The holding room was kept on a 10 L:14 D photoperiod and maintained at about $22^{\circ} \mathrm{C}$. The length of time that the muskrats were held in the lab prior to testing varied from a few days to 5 months. There were no apparent changes in the quality of the coats of the animals that were held in the lab for extended periods, nor were there any apparent differences in the data collected from animals caught at different times.

Oxygen consumption and body temperature $\left(\mathrm{T}_{\mathrm{B}}\right)$ were determined for muskrats tested in air and water at temperatures ranging from $5^{\circ} \mathrm{C}$ to $30^{\circ} \mathrm{C}$. At the beginning of each test, an animal's $\mathrm{T}_{\mathrm{B}}$ and weight (nearest $\mathrm{g}$ ) were recorded. Body temperatures were measured to the nearest tenth of a degree with a Yellow Springs Instruments telethermometer probe inserted rectally $8 \mathrm{~cm}$. The animal was then placed in a small hardware cloth cage to restrict its activity. This cage was then placed either on the floor of a room in which the temperature could be controlled to within $\pm 0.5^{\circ} \mathrm{C}$, or in a 45 gallon water bath within this room.

Cages were set in the water bath at about a $30^{\circ}$ angle, so that only one end of the cage extended out of the water. As a result, the animals were forced to remain submerged, with the exception of their heads, which could be raised out of the water at the high end of the cage. The water in the bath was gently agitated by two airstones to assure a uniform temperature throughout the bath (this was checked periodically). The animal was removed from the room or the bath after $45 \mathrm{~min}$, and its body temperature was again recorded.

Oxygen consumption was measured with a Beckman F-3 paramagnetic oxygen analyzer. A flow rate of 2.531 of air/min (STP) was used in a negative pressure open circuit system. Air was pulled through a respirometer system and then passed through columns of Ascarite and Drierite as in condition "B" defined by $\mathrm{Hill}$ (1972). The respirometer system used in air consisted of a sealed metal can (ca. $201)$ with one small inlet hole at the end opposite the outlet port. The muskrat sat on a wire-mesh grid in the can. The respirometer system used in water consisted of a plexiglass cap which fit over the high end of the partially sumberged animal cage in the water bath so that all of the edges of the cap were submerged and the animal could breathe in this cap. Room air was drawn in through small holes at the rear of the cap and drawn out through a hole in the front of the cap. 
On two occasions, muskrats were fasted for $48 \mathrm{~h}$ prior to testing (4 individuals on one occasion, 5 individuals on the other occasion). During this period all food was removed from the cages, but water was provided ad libitum.

Values reported are means plus or minus one standard deviation. Sample sizes are given in parentheses. Most data comparisons were unpaired t-tests unless stated otherwise.

\section{RESULTS}

\section{Body Temperature}

Muskrats regulated $T_{B}$ fairly well when exposed to air temperatures between 5 and $25^{\circ} \mathrm{C}$ (Table 1). However, the $\mathrm{T}_{\mathrm{B}}$ response at $30^{\circ} \mathrm{C}$ is significantly $(\mathrm{P}<0.05)$ higher than responses at lower $\mathrm{T}_{\mathrm{A}}$ exposures.

Table 1

Body temperature of muskrats exposed to different air and water temperatures.

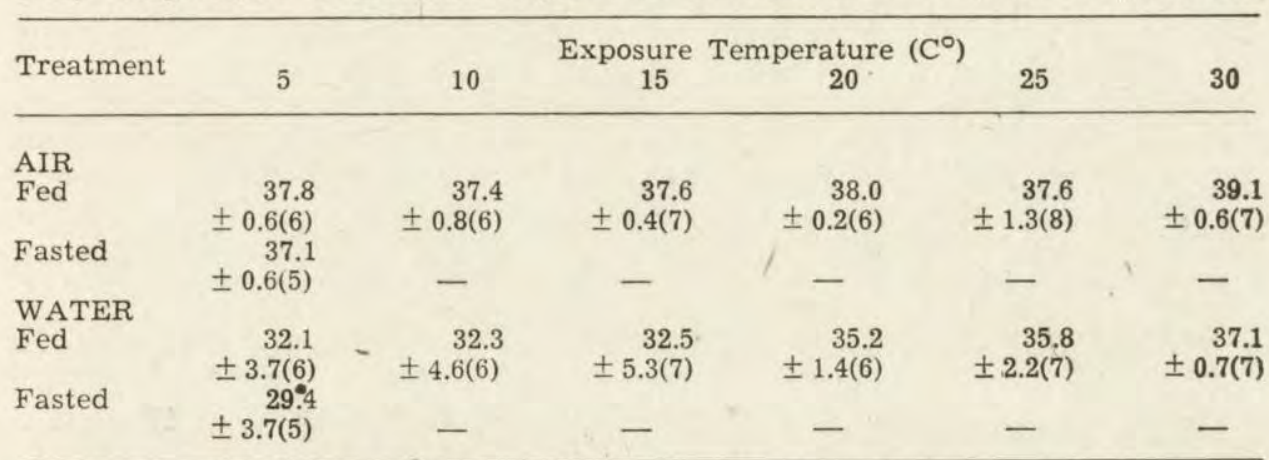

Values given are means \pm 1 standard deviation. Number in parentheses is sample size.

When placed in water at any temperature between 5 and $30^{\circ} \mathrm{C}$, muskrats showed a drop in $T_{B}$ from levels maintained at the same air temperature (Table 1). Also the variability of the responses was much greater in water than in air as shown by the variances of $T_{B}$ responses (Table 1). Although the lowest $T_{B}$ responses were shown at the lowest exposure temperatures, there is no strong relation between $T_{B}$ response and water temperature, which suggests that the lower $T_{B}$ responses are a regulated response.

Fasting for $48 \mathrm{~h}$ had no significant effect on thermoregulation of muskrats tested at $5^{\circ} \mathrm{C}$ in either air or water (Table 1). Although the $\mathrm{T}_{\mathrm{B}}$ 's of muskrats which had been fasted were lower than those of animals which had not been fasted, they were not statistically significantly $(P<0.05)$ lower. 
Muskrats that were unaccustomed to being handled tended to show a greater degree of hypothermia when placed in water than did experienced animals. The average drop in $T_{B}$ for the 5 muskrats that were tested for the first time in water at $5^{\circ} \mathrm{C}$ was $9.8^{\circ} \mathrm{C}$ compared to $4.4^{\circ} \mathrm{C}$ for experienced muskrats. Two muskrats were first tested in water at $10^{\circ} \mathrm{C}$, and their average drop in $\mathrm{T}_{\mathrm{B}}$ was $14.7^{\circ} \mathrm{C}$ compared to $3.2^{\circ} \mathrm{C}$ for experienced muskrats. Hence, only animals which had experienced handling were used in the analysis presented in Table 1.

\section{Metabolism}

Although the data are limited, the thermoneutral zone of muskrats appears to extend down to $10^{\circ} \mathrm{C}$ (Fig. 1). This has also been found by

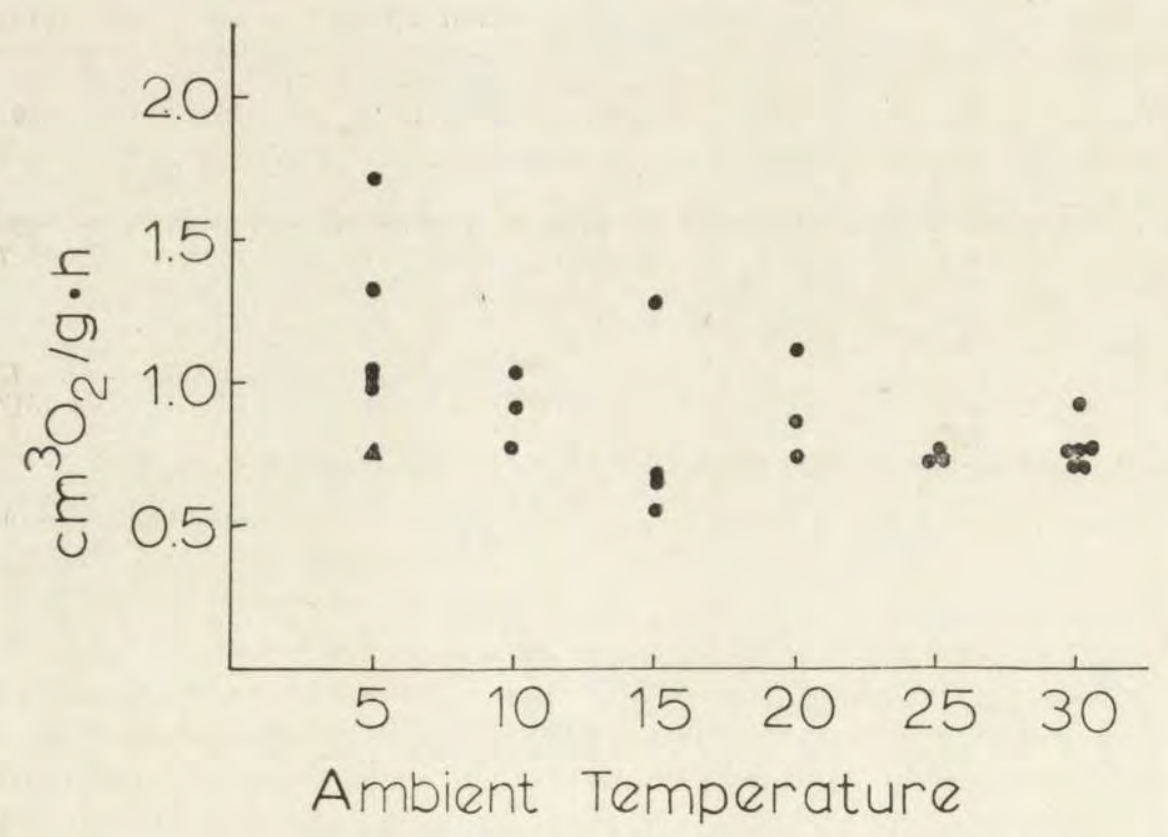

Fig. 1. Oxygen consumption of muskrats at different air temperatures. The triangle represents the value for one fasted animal.

McEwan et al. (1974). The resting metabolic rate for 19 measurements on 10 muskrats exposed to $\mathrm{T}_{\mathrm{A}}$ 's of 10 to $30^{\circ} \mathrm{C}$ was $0.82 \pm 0.07 \mathrm{~cm}^{3}$ $\mathrm{O}_{2}(\mathrm{~g} \cdot \mathrm{hr})^{-1}$. The average weight of these animals was $842.0 \pm 117 \mathrm{~g}$.

When placed in cold water, muskrats responded in one of two manners (Fig. 2). In some cases muskrats elevated their metabolic rate and there- 
fore, became only slightly hypothermie. In other instanees, the muskrats did not elevate their metabolic rate upon exposure to cold water. These muskrats became very hypothermic.

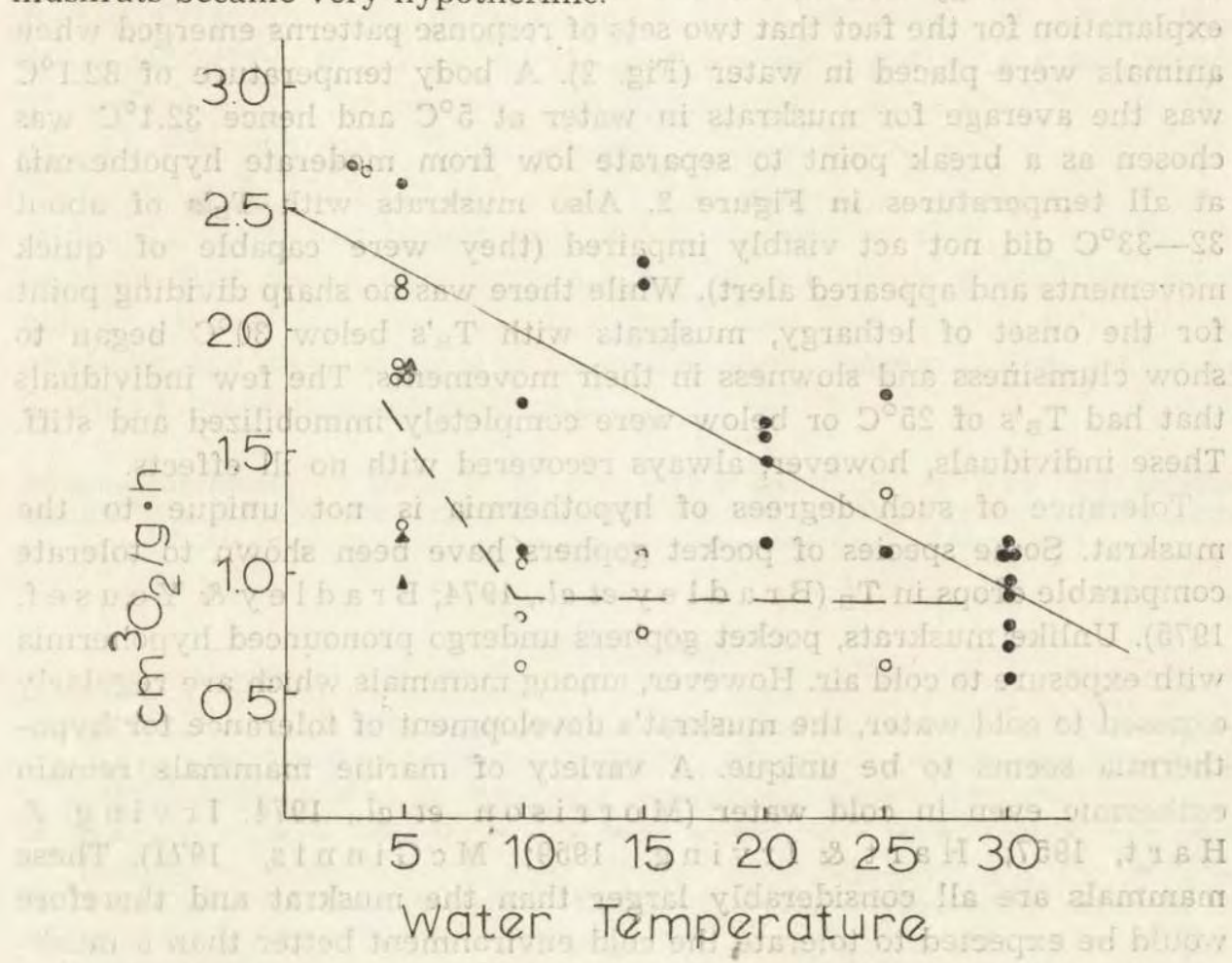

Fig. 2. Oxygen consumption of muskrats in water of different temperatures.

Triangles represent fasted $(48 \mathrm{hr})$ animals. Circles represent non-fasted animals. Unshaded circles represent animals with $\mathrm{T}_{\mathrm{B}}<32.1^{\circ} \mathrm{C}$ and shaded circles animals with $\mathrm{T}_{\mathrm{B}}>32.1^{\circ} \mathrm{C}$. The dashed line was fitted by eye for non-fasted animals with $\mathrm{T}_{\mathrm{B}}<32,1^{\circ} \mathrm{C}$ and the solid line by linear regression for non-fasted animals with $\mathrm{T}_{\mathrm{B}}>32.1^{\circ} \mathrm{C}$

\section{DISCUSSION}

Within the limits of our experimental conditions, muskrats are able to maintain normal $\mathrm{T}_{\mathrm{B}}$ when exposed to cold air and do so with relatively little variance in regulated levels. However, when stressed by cold in the more highly conductive water, virtually all animals sustained some degree of hypothermia even at expossures êf $25^{\circ} \mathrm{C}$. The fact that there is no strong correlation of $T_{B}$ with temperature of exposure suggests the animals $»$ regulate this hypothermia to some degree. Otherwise one would expect much greater levels of hypothermia at the lowest exposures and yet there is no difference in $T_{B}$ responses to ambient 
exposures of $5-20^{\circ} \mathrm{C}$. Some degree of hypothermia may be advantageous in reducing the gradient between body and ambient temperature and hence the energy needed for thermoregulation. However, we have no explanation for the fact that two sets of response patterns emerged when animals were placed in water (Fig. 2). A body temperature of $32.1^{\circ} \mathrm{C}$ was the average for muskrats in water at $5^{\circ} \mathrm{C}$ and hence $32.1^{\circ} \mathrm{C}$ was chosen as a break point to separate low from moderate hypothermia at all temperatures in Figure 2. Also muskrats with $T_{B}$ 's of about $32-33^{\circ} \mathrm{C}$ did not act visibly impaired (they were capable of quick movements and appeared alert). While there was no sharp dividing point for the onset of lethargy, muskrats with $\mathrm{T}_{\mathrm{B}}$ 's below $30^{\circ} \mathrm{C}$ began to show clumsiness and slowness in their movements. The few individuals that had $\mathrm{T}_{\mathrm{B}}$ 's of $25^{\circ} \mathrm{C}$ or below were completely immobilized and stiff. These individuals, however, always recovered with no ill effects.

Tolerance of such degrees of hypothermia is not unique to the muskrat. Some species of pocket gophers have been shown to tolerate comparable drops in $\mathrm{T}_{\mathrm{B}}$ ( $\mathrm{Br}$ a d l e y et al., 1974; $\mathrm{B} \mathrm{r}$ a d l e y \& Y o u s e f, 1975). Unlike muskrats, pocket gophers undergo pronounced hypohermia with exposure to cold air. However, among mammals which are regularly exposed to cold water, the muskrat's development of tolerance for hypothermia seems to be unique. A variety of marine mammals remain euthermic even in cold water (Morrison et al., 1974; Irving \& Hart, 1957; Hart \& Irving, 1959; McG inn is, 1971). These mammals are all considerably larger than the muskrat and therefore would be expected to tolerate the cold environment better than a muskrat.

The thermal neutral zone (TNZ) for muskrats in our study and those studied by $\mathrm{Hart}$ (1962) and $\mathrm{McE}$ w a n et al. (1974) extends down to $10^{\circ} \mathrm{C}$. Resting oxygen consumption in the $T N Z$ is about what one would expect for animals of this size from allometric relations (M o r r is o n et al., 1959). However, these animals are members of the subfamily Microtinae which are reported to have high metabolism ( $\mathrm{Packard}$, 1968; but see Wunder et al. 1977). Thus the "normal « metabolism may reflect good insulation from pelage.

$\mathrm{McEw}$ a $\mathrm{n}$ et al. (1974) showed that resting metabolic rates of muskrats fasted for $48 \mathrm{~h}$ were as much as $40 \%$ lower than those of muskrats which were well fed. Thus, one might expect $T_{B}$ 's of fasted animals to be lower than those of well fed animals. Although the $T_{B}$ 's we report for fasted muskrats are numerically lower than those of well fed individuals, they are not statistically significantly lower. However, M c$\mathrm{Ewan}$ et al. (1974) also reported that fasted muskrats have the capability of raising their metabolic rate as high or higher than well fed 
muskrats when exposed to very cold air temperatures. It is reasonable to assume, then, that fasted muskrats placed in water may elevate their metabolism to the same level as fed muskrats under the same conditions. But, as shown in Figure 2, fasted muskrats in our study did not elevate their metabolism to the extent that fed muskrats did, as a result some of these animals became severely hypothermic. Several of the fasted animals dropped their $\mathrm{T}_{\mathrm{B}}$ low enough to be dangerously lethargic and uncòordinated. While one can easily see an advantage, in terms of energy savings, in becoming hypothermic when stressed by cold, it is difficult to argue that severe hypothermia could have adaptive advantages. Any energy savings incurred by the reduced heat loss would certainly be offset by the disadvantages of being lethargic, uncoordinated, and vulnerable to predation and drowning.

Acknowledgement: We thank G. C. P a ckard and C. R. Tracy for helpful comments and P. R e y olds for drawing the figure. The study was funded from an NIH-BRSG grant to CSU and a Faculty Research Grant from CSU.

\section{REFERENCES}

1. A leksiuk M. \& Frohlinger A., 1971: Seasonal metabolic organization in the muskrat (Ondatra zibethica). I. Changes in growth, thyroid activity, brown adipose tissue, and organ weights in nature. Can. J. Zool., 49: 1143-1154.

2. Bradley W. G., Miller J.S. \& Yousef M. K., 1974: Thermoregulatory patterns in pocket gophers: desert and mountain. Physiol. Zöol., 47: 172-179.

3. Bradley W. G. \& Yousef M. K., 1975: Thermoregulatory responses in the Plains Pocket Gopher, Geomys bursarius. Comp. Biochem. Physiol., 52A: $35-38$.

4. Fairbanks E. S. \& Kilgore D. L. Jr., 1978: Post-dive oxygen consumption of restrained and unrestrained muskrats (Ondatra zibethica). Comp. Biochem. Physiol., 59A: 113-117.

5. Hart J. S., 1962: Temperature regulation and adaptation to cold climates. [In: "Comparative Physiology of Temperature Regulation", Eds J. P. Hannon and E. Viereck]. Arctic Aeromedical Lab., Fort Wainwright, Alaska.

6. Hart J. S. \& I rving L., 1959: The energetics of harbor seals in air and water, with special consideration of seasonal changes. Can. J. Zool., 37: 447-457.

7. Hill R. W., 1972: Determination of oxygen consumption by use of the paramagnetic oxygen analyzer. J. Applied Physiol., 33: 261-263.

8. Irving L., Hart J. S., 1957: The metabolism and insulation of seals as bare-skinned mammals in cold water. Can. J. Zool., 35: 497-511.

9. J o hansen K. 1962: Buoyancy and insulation in the muskrat. J. Mamm., 43. 64-68.

10. McEwan E. H., Aitchison \& Whitehead P. E., 1974: Energy metabolism of oiled muskrats. Can. J. Zool., 52: 1057-1062.

11. McGinnis S. M., 1971: Thermoregulation in the northern elephant seal. Comp. Biochem. Physiol., 40A: 893-896. 
12. Morrison P. R., Ryser F. A. \& Dawe A. R, 1959: Studies on the physiology of the masked shrew, Sorex cinereus. Physiol. Zool, 32: 256-271.

13. Morrison P., Rosenmann M. \& Estes J. A., 1974: Metabolism and thermoregulation in the sea otter. Physiol. Zool., 47: 218-226.

14. Packard G. C., 1968: Oxygen consumption of Microtus montanus in relation to ambient temperature. $\mathcal{~ Y . ~ M a m m . , ~ 4 9 : ~} 215-220$.

15. Wunder B. A., Dobkin D. \& Gettinger R., 1977: Shifts of thermogenesis in the prairie vole (Microtus ochrogaster): strategies for survival in a seasonal environment. Oecologia, 29: 11-26.

Accepted, November $14,1978$.

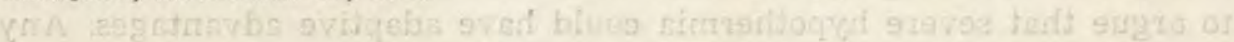

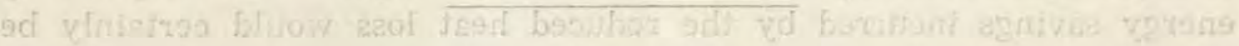

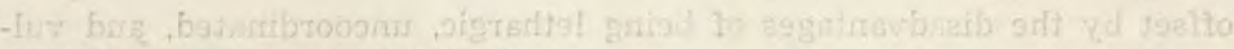
Jon SHERER i Bruce A. WUNDER

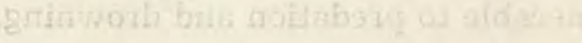

mo11 bERMOREGULACJA U PIZMAKA NA POWIETRZU I W WODZIE

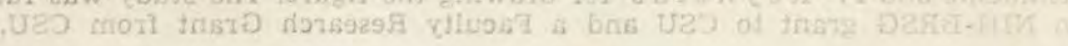

Streszczenie

Dokonano pomiarów tempa zuzycia tlenu $\mathrm{i}$ temperatury ciała $\left(\mathrm{T}_{\mathrm{B}}\right)$ u piżmaka Ondatra zibethicus (Linnaeus, 1766), Zwierzęta były przetrzymywane przez 45 minut, w wodzie lub na powietrzu, w zakresie temperatur od 5 do $30^{\circ} \mathrm{C}$. Stwierdzono, że na powietrzu piżmaki utrzymują stała $\mathrm{T}_{\mathrm{B}}$, w zakresie $37-39^{\circ} \mathrm{C}$, ale podlegają hipotermii po okresie przetrzymywanie w chłodnej wodzie i przy temperaturze 5 i $10^{\circ} \mathrm{C}$ ich $\mathrm{T}_{\mathrm{B}}$ wynosiła niewiele ponad $32^{\circ} \mathrm{C}$ u osobników najedzonych, zaś u piżmaków głodzonych przed pomiarami, $T_{B}$ przy $5^{\circ} \mathrm{C}$ wynjosła zaledwie $29,4^{\circ} \mathrm{C}$ (Tabela 1).

Jakkolwiek wszystkie badane osobniki zniżały $\mathrm{T}_{\mathrm{B}}$ po pobycie $\mathrm{w}$ wodzie, to niektóre $\mathrm{z}$ nich wzmogły tempo metabolizmu i te podlegały tylko niewielkiemu spadkowi $T_{B}$, natomiast inne osobniki nie reagowały zwiększeniem zużycia tlenu, a ich temperatura ciała zniżała się znacznie (Ryc. 2), Na powietrzu krzywa termoregulacji nie odbiega od wartości właściwej wielu innym gatunkom gryzoni (Ryc. 1).

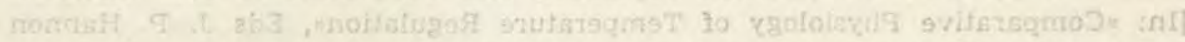

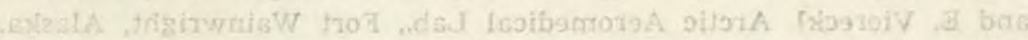

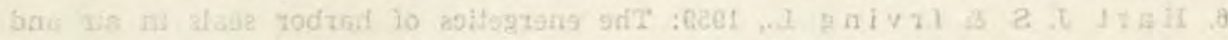

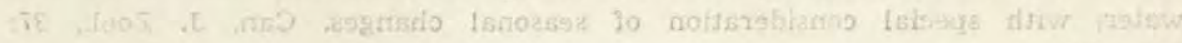

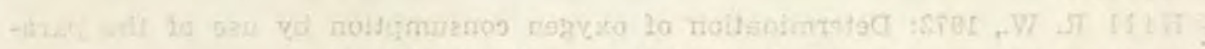

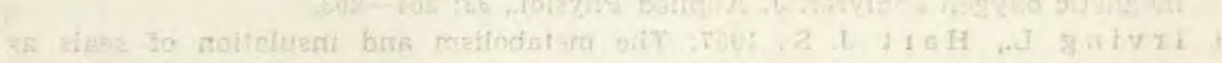

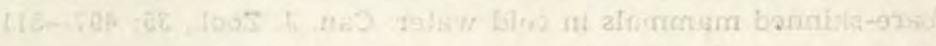

